\title{
Induction of $\mathrm{Na}^{+} / \mathrm{K}^{+}$-ATPase activity by long-term stimulation of nicotinic acetylcholine receptors in $\mathrm{C} 2 \mathrm{C} 12$ myotubes
}

\author{
${ }^{1}$ R.H. Henning, S.A. Nelemans, J. van den Akker \& A. den Hertog
}

Department of Pharmacology/Clinical Pharmacology, University of Groningen, Bloemsingel 1, 9713 BZ Groningen, The Netherlands

1 To investigate the role of long-term stimulation of nicotinic acetylcholine receptors (AChRs) on the regulation of membrane potential, non-contracting $\mathrm{C} 2 \mathrm{C} 12$ myotubes were stimulated for $1-4$ days with carbachol $(10 \mu \mathrm{M})$ and membrane potentials were measured by the intracellular microelectrode technique after washing out of the drug.

2 The membrane potential $(-45.7 \mathrm{mV})$ gradually increased by $10.1 \mathrm{mV}$ to $-55.8 \mathrm{mV}$ during 4 days treatment, which was caused by enhanced electrogenic $\mathrm{Na}^{+} / \mathrm{K}^{+}$-pumping.

3 The concentration-dependent enhancement of $\mathrm{Na}^{+} / \mathrm{K}^{+}$-ATPase activity in long-term carbacholtreated myotubes $\left(4\right.$ days, $\left.\mathrm{EC}_{50}=5.3 \mu \mathrm{M}\right)$ was prevented by co-treatment with the competitive nicotinic AChR antagonist, pancuronium but not by the muscarinic antagonist, atropine.

4 Enhanced $\mathrm{Na}^{+} / \mathrm{K}^{+}$-ATPase activity still developed in carbachol-stimulated myotubes during cotreatment (4 days) with the nicotinic AChR-channel blocker, chlorpromazine $(1 \mu \mathrm{M})$. Membrane depolarization as such, obtained by incubation in high $\mathrm{K}^{+}$medium $(40 \mathrm{mM}, 4$ days) did not enhance $\mathrm{Na}^{+} / \mathrm{K}^{+}$-ATPase activity.

5 Non-treated myotubes possessed a high-affinity ouabain binding site $\left(K_{d}=119 \mathrm{nM}\right)$ in association with the low $\mathrm{Na}^{+} / \mathrm{K}^{+}$-pumping activity. Long-term stimulation of myotubes (4 days) with carbachol or with a combination of carbachol and chlorpromazine was accompanied by the development of an additional low-affinity ouabain binding site $\left(K_{\mathrm{d}}=13 \mu \mathrm{M}\right)$.

6 Binding of monoclonal antibodies directed against either $\alpha_{1^{-}}$or $\alpha_{2}$-subunit of $\mathrm{Na}^{+} / \mathrm{K}^{+}$-ATPase were both increased in myotubes treated with carbachol (4 days).

7 These results support the concept that nicotinic AChRs regulate $\mathrm{Na}^{+} / \mathrm{K}^{+}$-ATPase activity, independent of the functionality of the receptor-operated ion-channel.

Keywords: $\mathrm{Na}, \mathrm{K}$ transporting ATPase; nicotinic acetylcholine receptor; $\mathrm{C} 2 \mathrm{C} 12$ myotubes

\section{Introduction}

Long-term interruption of neuromuscular transmission by drugs or toxins induces denervation-like changes in skeletal muscle (Chang et al., 1975; Simpson, 1977). Thus, long-term administration of competitive blockers of the nicotinic acetylcholine receptor (AChR) is associated with the development of extrajunctional nicotinic AChRs and a decrease in membrane potential (Berg \& Hall, 1975; Pestronk et al., 1980). The development of these properties is thought to be related to the cessation of muscle contraction, for they are almost completely counteracted by direct stimulation (Drachman \& Witzke, 1972). However, the disruption of stimulation of nicotinic AChRs might also contribute to the effects observed on long-term administration of competitive blockers. Indeed, some studies suggest a trophic role for $\mathrm{ACh}$. For instance, it has been found that drugs interfering only with nerve impulse-dependent $\mathrm{ACh}$ release induce less extrajunctional nicotinic AChRs than agents that block spontaneous ACh release as well (Pestronk et al., 1976; Mathers \& Thesleff, 1978). Moreover, a possible role for nicotinic AChRs is strongly supported by a study demonstrating denervation-like changes in the skeletal muscle of animals that had been chronically treated with low concentrations of the nicotinic AChR antagonist (+)-tubocurarine not interfering with muscular contraction (Hogue et al., 1992). To examine the role of nicotinic AChRs in the regulation of skeletal muscle properties, we studied the effect of long-term stimulation of nicotinic AChRs on the membrane potential of noninnervated, non-contracting $\mathrm{C} 2 \mathrm{C} 12$ myotubes.

\footnotetext{
${ }^{1}$ Author for correspondence.
}

Methods

\section{Cell culture}

C2C12 cells, a murine myoblast cell line (Yaffee \& Saxel, 1977) were obtained from the American Tissue Type Collection, Rockville, U.S.A. Cells were cultured, for most experiments on glass cover slips, in $9.6 \mathrm{~cm}^{2}$ plastic wells at $37^{\circ} \mathrm{C}$ in Dulbecco's modified essential medium, $7 \mathrm{mM} \mathrm{NaHCO}$ and $10 \mathrm{mM}$ HEPES (DMEM) supplemented with $10 \%$ foetal calf serum. When cells reached $80 \%$ confluence, medium was changed to DMEM supplemented with $5 \%$ horse serum (HS). Low $\mathrm{Na}^{+}(23 \mathrm{mM})$ medium was obtained by diluting DMEM with medium of the following composition (mM): glucaminechloride $125, \mathrm{KCl} 6, \mathrm{CaCl}_{2} 1.2, \mathrm{MgCl}_{2} 2.5, \mathrm{NaH}_{2} \mathrm{PO}_{4}$ 1.2 , glucose 11 , HEPES 10 , HS $5 \%$ (pH 7.4). High $\mathrm{K}^{+}$ (60 mM) medium was obtained by mixing DMEM with medium of the following composition (mM): $\mathrm{KCl} 131, \mathrm{CaCl}_{2}$ 1.2, $\mathrm{MgCl}_{2} 2.5, \mathrm{NaH}_{2} \mathrm{PO}_{4} 1.2$, glucose 11, HEPES 10, HS $5 \%$ (pH 7.4). Control medium was obtained by appropriately diluting DMEM with medium of the following composition (mM): $\mathrm{NaCl} 125, \mathrm{KCl} 6, \mathrm{CaCl}_{2} 1.2, \mathrm{MgCl}_{2} 2.5, \mathrm{NaH}_{2} \mathrm{PO}_{4}$ 1.2, glucose 11, HEPES 10 (pH 7.4). Myotubes were used 7 days after initiating myoblast fusion. Spontaneous contractions of the myotubes were not observed.

\section{Electrophysiology}

Membrane potential was measured by microelectrodes filled with $1 \mathrm{M} \mathrm{KCl}$ as described previously (Henning et al., 1992). Experiments were performed following a $15 \mathrm{~min}$ wash at $25^{\circ} \mathrm{C}$ in a $1 \mathrm{ml}$ bath superfused at a rate of $1.5 \mathrm{ml} \mathrm{min}^{-1}$ with the following solution $(\mathrm{mM}): \mathrm{NaCl} 125, \mathrm{KCl} 6, \mathrm{CaCl}_{2}$ 1.2, 
$\mathrm{MgCl}_{2}$ 2.5, $\mathrm{NaH}_{2} \mathrm{PO}_{4}$ 1.2, glucose 11, HEPES 10 (pH 7.4). In the low $\mathrm{Na}^{+}$solution $(23 \mathrm{mM}), \mathrm{NaCl}(102 \mathrm{mM})$ was replaced with glucaminechloride. Drugs used were applied by changing the superfusing fluid with buffer containing the required drug concentration.

\section{$\left[{ }^{3} \mathrm{H}\right]$-ouabain binding}

The number of $\left[{ }^{3} \mathrm{H}\right]$-ouabain binding sites was determined by measuring the specific binding of $\left[{ }^{3} \mathrm{H}\right]$-ouabain at several ouabain concentrations $(20 \mathrm{nM}-1 \mu \mathrm{M})$. Total binding at $20^{\circ} \mathrm{C}$ was assessed in buffer of the following composition (mM): $\mathrm{NaCl} 150, \mathrm{MgCl}_{2} 4$, HEPES 10 (pH 7.4). Non-specific binding was determined in a buffer of the following composition (mM): $\mathrm{KCl} \mathrm{150,} \mathrm{MgCl}_{2} 4$, HEPES 10 (pH 7.4). Cells were successively washed three times in the buffer, incubated for $30 \mathrm{~min}$ in $1 \mathrm{ml}$ buffer containing the final ouabain concentration including $\left.{ }^{3} \mathrm{H}\right]$-ouabain $\left(0.5-3.0 \mu \mathrm{Ci} . \mathrm{ml}^{-1}\right)$ and washed four times with ice-cold buffer. A final wash was performed with additional $2 \%$ ethanol. Thereupon, cells were solubilized in $1 \mathrm{ml} \mathrm{NaOH}(1 \mathrm{M})$ and radioactivity was measured by liquid scintillation counting. Data were subjected to kinetic modelling (Munson \& Rodbard, 1980). A two-site binding model was preferred over a one-site binding model if a significant reduction in the residual sum of squares of the fitted curve was obtained ( $F$ test, $P<0.05$ ).

\section{Analysis of $\mathrm{Na}^{+} / \mathrm{K}^{+}-$ATPase antibody binding}

Two monoclonal antibodies were used (courtesy of Dr K.J. Sweadner). McK1 is a mouse $\mathrm{IgG}_{1}$ antibody raised against rat kidney $\mathrm{Na}^{+} / \mathrm{K}^{+}$-ATPase, which cross-reacts with the $\alpha_{1-}$ subunit of both native and denatured mouse $\mathrm{Na}^{+} / \mathrm{K}^{+}-\mathrm{ATP}-$ ase (Felsenfeld \& Sweadner, 1988). McB2 is a mouse $\mathrm{IgG}_{1}$ antibody raised against rat axolemma $\mathrm{Na}^{+} / \mathrm{K}^{+}$-ATPase and recognizes the $\alpha_{2}$ subunit of the native and denatured enzyme (Urayama et al., 1989). Staining procedure consisted of an initial wash $(30 \mathrm{~min})$ of cells grown on monolayers on glass coverslips, followed by fixation for $30 \mathrm{~min}$ in periodatelysine-paraformaldehyde, an overnight wash in $0.02 \mathrm{M}$ potassium phosphate buffered saline (KPBS, pH 7.4) and treatment with Triton $\mathrm{X}-100(0.3 \%)$ and $\mathrm{H}_{2} \mathrm{O}_{2}(10 \%)$ in KPBS for three periods of $10 \mathrm{~min}$. After washing with KPBS containing $0.3 \%$ Triton X-100 (KPBS-T), the monolayers were incubated with McK1 (dilution 1:24) or McB2 $(1: 10)$ for $60 \mathrm{~h}$. Secondary antibodies (RAM/IgG $(\mathrm{H}+\mathrm{L}), 1: 400$, Nordic Immunological Lab, Tilburg, the Netherlands) were introduced for $2 \mathrm{~h}$ after washing in KPBS-T. After washing, cells were subsequently incubated with rabbit peroxidase-antiperoxidase $(1: 800$, Nordic) in a solution containing $0.05 \%$ 3,3-diaminobenzidine (DAB), $2.5 \%$ nickel ammonium sulphate (NAS), $0.04 \%$ ammonium chloride and $0.004 \% \mathrm{H}_{2} \mathrm{O}_{2}$. Staining intensity was determined after washing in KPBS-T by scanning the absorbance of the cells at $497 \mathrm{~nm}$ (100 pixels at $10 \mu \mathrm{m}$ distance in an area of $200 \times 200 \mu \mathrm{m}$ ) using a Leitz orthoplan microscope with $10 \times$ objective and equipped with a Leitz MPV compact photometer with scanning stage control unit as described by Wolters et al. (1984). Coverslips were scanned at 20 randomly chosen areas. Data were corrected for non-specific absorbance of the cells and are presented as mean \pm s.e.mean of the absorbance. Control coverslips with treated and non-treated myotubes that were processed without incubation with the primary or secondary antibody did not stain.

\section{Results}

\section{Membrane potential: acute effects of carbachol}

In acute experiments, the non-hydrolysable AChR agonist, carbachol $(1-30 \mu \mathrm{M})$ evoked a sustained and reproducible depolarization of the cells (Figure 1a). The amplitude of the
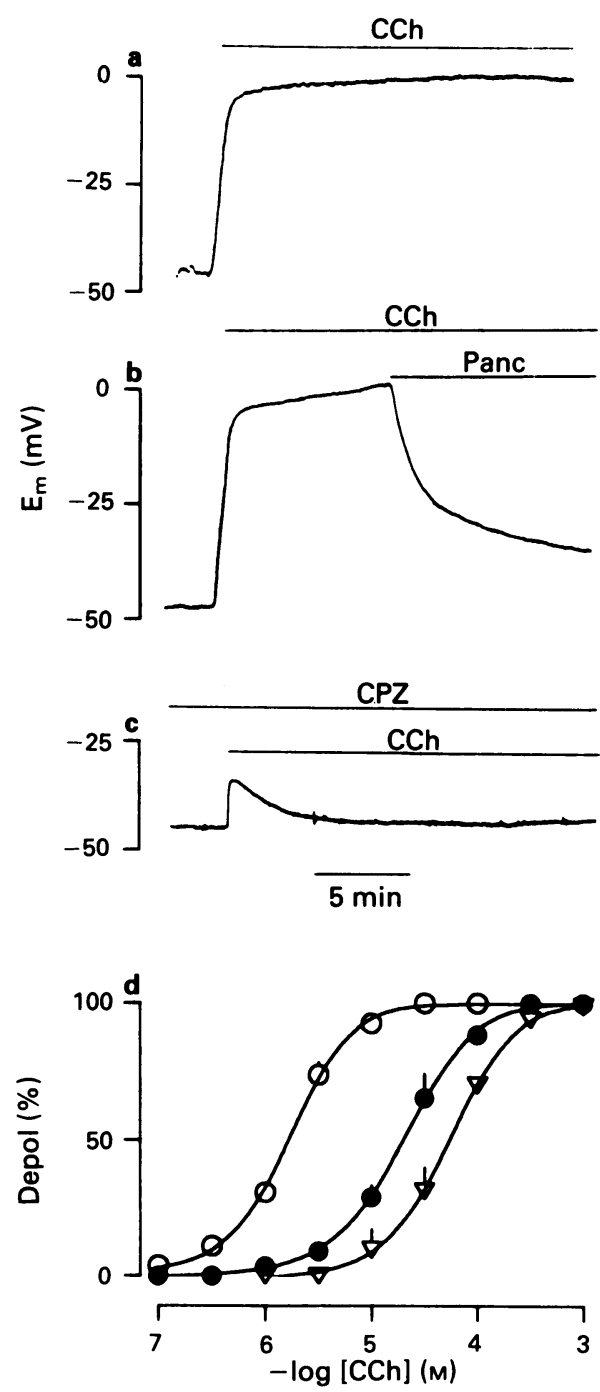

Figure 1 The acute effect of carbachol $(\mathrm{CCh})$ on membrane potential $\left(\mathrm{E}_{\mathrm{m}}\right)$ of $\mathrm{C} 2 \mathrm{C} 12$ myotubes under different experimental conditions. (a) Recording of the sustained depolarization evoked by carbachol $(10 \mu \mathrm{M}$; horizontal bar); (b) the antagonistic effect of pancuronium (Panc, $1 \mu \mathrm{M}$; horizontal bar); (c) use-dependent block by chlorpromazine (CPZ, $1 \mu \mathrm{M})$; (d) concentration-effect curve of carbachol ( $O$; $n=6)$ and in the presence of pancuronium $(0.3 \mu \mathrm{M}, 0 ; n=4)$ and $(1 \mu \mathrm{M}, \nabla ; n=4)$. Data $( \pm$ s.e.mean $)$ are expressed as the percentage of the maximal depolarization $(43.4 \pm 2.2 \mathrm{mV} ; n=6)$.

depolarization was dependent on the agonist concentration, reaching a maximum at $30 \mu \mathrm{M}(43.4 \pm 2.2 \mathrm{mV} ; n=6)$. This action of carbachol was inhibited by the competitive nicotinic AChR antagonist, pancuronium (Figures $1 \mathrm{~b}, \mathrm{~d}$ ), but not by the muscarinic receptor antagonist, atropine $(1 \mu \mathrm{M}$; not shown). Under low $\mathrm{Na}^{+}$conditions $(23 \mathrm{mM})$, the depolarization evoked by carbachol $(30 \mu \mathrm{M})$ was greatly reduced, being $9.2 \pm 1.0 \mathrm{mV}(n=6)$. Chlorpromazine is known to block the nicotinic AChR-coupled ion-channel use-dependently (Changeux, 1990). In fact, carbachol $(10 \mu \mathrm{M})$ evoked only an initial depolarization in the presence of chlorpromazine $(1 \mu \mathrm{M}$; Figure 1c).

\section{Membrane potential: long-term effects of carbachol}

The effect of chronic stimulation of the nicotinic AChRs was studied by treatment of the $\mathrm{C} 2 \mathrm{C} 12$ myotubes for several days with carbachol and assessed by measuring their membrane potential in the absence of the agonist ( $\geqslant 15 \mathrm{~min}$ ). Nontreated myotubes possessed a relative small membrane potential of about $-46 \mathrm{mV}$ and inhibition of $\mathrm{Na}^{+} / \mathrm{K}^{+}$-pumping by ouabain $(200 \mu \mathrm{M})$ resulted in a minor reduction of their 
Table 1 The effect of long-term stimulation of nicotinic acetylcholine receptors (AChRs) on membrane potential of C2C12 myotubes

\begin{tabular}{|c|c|c|c|c|c|}
\hline Treatment & $\begin{array}{c}\text { Incubation } \\
\mathbf{E}_{\mathrm{m}}^{\dagger} \\
(\mathrm{mV})\end{array}$ & $\underset{(\mathrm{mV})}{\mathrm{E}_{\mathrm{m}}} A f t$ & $\begin{array}{l}\text { ng } \\
\mathrm{E}_{\mathrm{m}}(\mathrm{Ouab}) \\
\quad(\mathrm{mV})\end{array}$ & $\underset{(\mathrm{mV})}{\mathrm{V}_{\mathrm{el}}}$ & $\mathrm{n}$ \\
\hline $\begin{array}{l}\text { None } \\
\text { Carbachol } \\
\text { Carbachol/CPZ } \\
\text { High K } \mathrm{K}^{+}\end{array}$ & $\begin{array}{r}-46.2 \pm 1.5 \\
-8.4 \pm 2.2 \\
-54.6 \pm 2.9 \\
-13.7 \pm 3.3\end{array}$ & $\begin{array}{l}-45.7 \pm 0.6 \\
-55.8 \pm 1.3^{*} \\
-52.9 \pm 1.3^{*} \\
-42.6 \pm 1.3\end{array}$ & $\begin{array}{l}-43.5 \pm 0.8 \\
-45.4 \pm 1.4 \\
-44.1 \pm 1.3 \\
-44.6 \pm 0.5\end{array}$ & $\begin{array}{c}-1.2 \pm 1.0 \\
-10.4 \pm 1.9^{*} \\
-8.8 \pm 1.8^{*} \\
-2.0 \pm 1.4\end{array}$ & $\begin{array}{l}30 \\
12 \\
12 \\
12\end{array}$ \\
\hline
\end{tabular}

membrane potential (1.2 mV; Table 1; Figure 2a). Myotubes incubated for 4 days with carbachol $(10 \mu \mathrm{M})$ maintained their depolarization in the presence of the agonist (Table 1). However, after removing carbachol $(10 \mu \mathrm{M})$, the myotubes showed a pronounced increase in membrane potential of about -10 $\mathrm{mV}$ compared to non-treated cells (Table 1; Figure 2a,b). Inhibition of $\mathrm{Na}^{+} / \mathrm{K}^{+}$-ATPase in carbachol-treated myotubes by ouabain $(200 \mu \mathrm{M})$ caused a significantly higher reduction in membrane potential than in non-treated cells (Figure $2 a, b$ Table 1). The membrane potential of non-treated and carbachol-treated cells reached comparable values in the presence of ouabain (Figure 2a,b; Table 1). The enhanced $\mathrm{Na}^{+} / \mathrm{K}^{+}$ATPase activity induced by carbachol $(10 \mu \mathrm{M})$ developed gradually during the 4 days treatment and declined slowly after withdrawal of the nicotinic AChR agonist (Figure 2c,d) Carbachol treatment for 4 days produced a concentrationdependent increase in electrogenic $\mathrm{Na}^{+} / \mathrm{K}^{+}$-pumping $\left(\mathrm{EC}_{50}=5.3 \mu \mathrm{M}\right.$; Figure $\left.2 \mathrm{e}\right)$, at similar concentrations to those observed in acute experiments (Figure 1d).
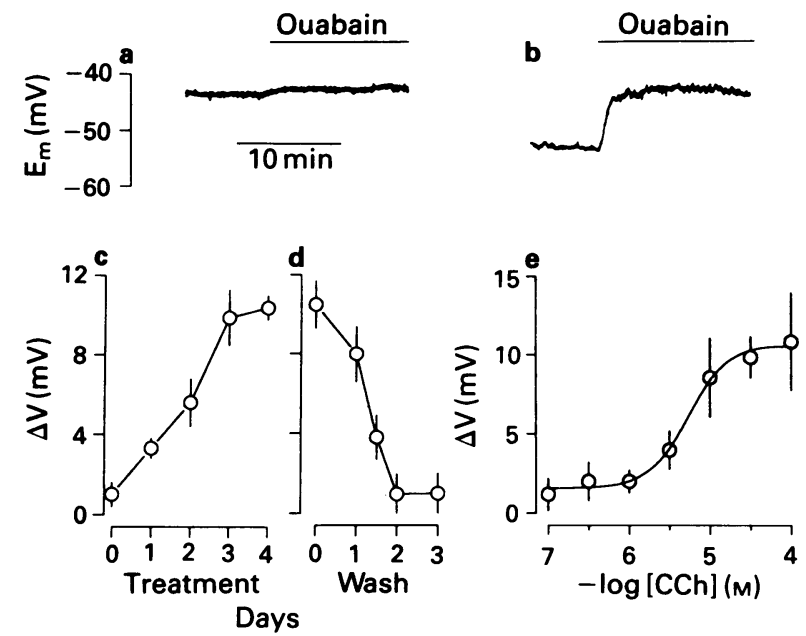

Figure 2 The effect of 4 days treatment of the cells with carbachol $(10 \mu \mathrm{M})$ on membrane potential and electrogenic $\mathrm{Na}^{+} / \mathrm{K}^{+}$-pumping in $\mathrm{C} 2 \mathrm{C} 12$ myotubes, measured in the absence of carbachol. (a) The membrane potential of non-treated cells showed a small reduction upon inhibition of electrogenic pumping with ouabain $(200 \mu \mathrm{M}$; horizontal bar); (b) treated cells showed a pronounced decrease in membrane potential in the presence of ouabain $(200 \mu \mathrm{M})$; (c) the development of electrogenic pumping in time during carbachol treatment; (d) the decline of electrogenic pumping in time after washing 4 days carbachol treated cells; (e) concentration-effect curve of the amount of electrogenic pumping after 4 days of treatment with various concentrations of carbachol $(0.1-100 \mu \mathrm{M})$. Values ( \pm s.e. mean) are expressed as the difference between membrane potential in the absence and presence of ouabain $(200 \mu \mathrm{M} ; n \geqslant 12)$.
To assure that the development of enhanced $\mathrm{Na}^{+} / \mathrm{K}^{+}$ATPase activity was mediated by nicotinic AChRs, myotubes were treated with carbachol (4 days) in the presence of identical concentrations of selective antagonists. Myotubes simultaneously treated with carbachol $(10 \mu \mathrm{M})$ and the nicotinic $A C h R$ antagonist, pancuronium $(1 \mu \mathrm{M})$ possessed the same membrane potential $(-46.8 \pm 1.7 \mathrm{mV} ; n=10)$ as non-treated or pancuronium-treated myotubes. Pancuronium-treated myotubes showed the same membrane potential as non-treated cells $(-45.0 \pm 2.9 ; n=6)$. In contrast, the muscarinic antagonist, atropine $(1 \mu \mathrm{M})$ did not prevent the increase in $\mathrm{Na}^{+} /$ $\mathrm{K}^{+}$-pumping of myotubes as observed in cells treated for 4 days with carbachol $(10 \mu \mathrm{M})$. A similar increase in membrane potential $(10.1 \pm 2.0 \mathrm{mV} ; n=12)$ as in carbachol-treated myotubes was observed in the presence of ouabain $(200 \mu \mathrm{M})$.

The development of enhanced $\mathrm{Na}^{+} / \mathrm{K}^{+}$-ATPase activity in long-term carbachol-stimulated myotubes might be due to the $\mathrm{Na}^{+}$-influx passing the receptor coupled ion-channel. This was investigated in myotubes treated for 4 days with carbachol and chlorpromazine, inhibiting the nicotinic AChR coupled $\mathrm{Na}^{+}$-influx (Figure 1c). In the presence of chlorpromazine, the carbachol-stimulated nicotinic AChR-channel was completely blocked, as demonstrated by the observation that the membrane potential of cells, treated for 4 days with carbachol $(10 \mu \mathrm{M})$ and chlorpromazine $(1 \mu \mathrm{M})$, still in the presence of both drugs $(-54.6 \mathrm{mV}$; Table 1$)$, did not change after withdrawal of carbachol $(-51.6 \pm 1.2 \mathrm{mV} ; n=8)$. After removing both drugs, myotubes treated with a combination of carbachol $(10 \mu \mathrm{M})$ and chlorpromazine $(1 \mu \mathrm{M})$ showed an increase in membrane potential comparable to that of long-term carbachol-treated cells (Table 1). Long-term treatment of the myotubes with chlorpromazine alone did not change the membrane potential $(-44.0 \pm 2.4 \mathrm{mV} ; n=10)$ compared to non-treated cells. Inhibition of the $\mathrm{Na}^{+} / \mathrm{K}^{+}$. ATPase by ouabain $(200 \mu \mathrm{M})$ of cells treated with carbachol $(10 \mu \mathrm{M})$ and chlorpromazine $(1 \mu \mathrm{M})$, caused a pronounced increase in membrane potential, as found in myotubes treated with carbachol alone (Table 1).

To investigate whether the development of $\mathrm{Na}^{+} / \mathrm{K}^{+}$-ATPase activity was related to the maintained depolarization of carbachol-treated myotubes, the effect of high $\mathrm{K}^{+}$medium ( $40 \mathrm{mM} ; 4$ days) was investigated. At the end of the incubation period, myotubes showed a depolarization of $32.5 \mathrm{mV}$ still in the presence of high $\mathrm{K}^{+}(40 \mathrm{mM})$ (Table 1$)$. Changing to normal conditions after the high $\mathrm{K}^{+}$treatment produced a normal membrane potential as observed in non-treated cells, not significantly affected by ouabain $(200 \mu \mathrm{M}$; Table 1$)$.

\section{$\mathrm{Na}^{+} / \mathrm{K}^{+}-\mathrm{ATPase}$ up-regulation}

Ouabain binding The nature of the development of enhanced $\mathrm{Na}^{+} / \mathrm{K}^{+}$-ATPase activity in carbachol-treated myotubes was investigated by determination of $\left[{ }^{3} \mathrm{H}\right]$-ouabain binding in the myotubes. Non-treated myotubes possessed a high-affinity site (Figure 3a, Table 2). In myotubes treated with carbachol $(10 \mu \mathrm{M})$ or a combination of carbachol and chlorpromazine 

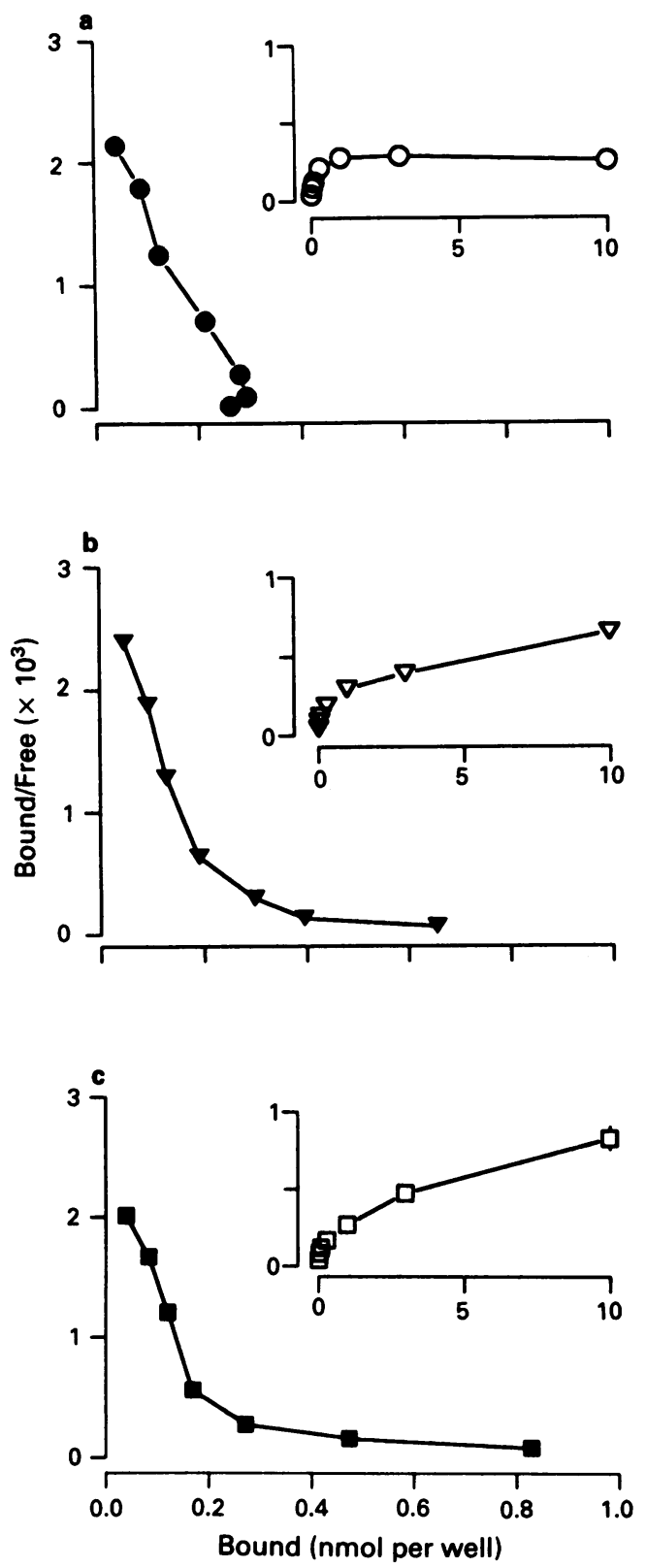

Figure 3 The effect of carbachol treatment of cells on ouabain binding represented by Scatchard plots and saturation binding curves (inserts). (a) A single high-affinity binding site was found in nontreated cells; (b) an additional low-affinity binding site was analysed after 4 days treatment with carbachol $(10 \mu \mathrm{M})$; (c) a high-affinity as well as a low-affinity binding site was also observed after 4 days treatment with carbachol $(10 \mu \mathrm{M})$ and chlorpromazine $(1 \mu \mathrm{M})$. Inserts: abscissae represent ouabain concentration $\left(\mu_{\mathrm{M}}\right)$, ordinates represent specific binding (nM); data are expressed as mean \pm s.e.mean. Binding parameters are provided in Table 2.
Table 3 The effect of treatment (4 days) with carbachol $(10 \mu \mathrm{M})$ on $\mathrm{Na}^{+} / \mathrm{K}^{+}$-ATPase-antibody binding in $\mathrm{C} 2 \mathrm{C} 12$ myotubes

\begin{tabular}{lcc} 
& \multicolumn{2}{c}{ Absorbance $(\times 100)$} \\
& Control & Carbachol \\
McK1 & $22.1 \pm 1.5$ & $32.2 \pm 1.1^{*}$ \\
McB2 & $22.9 \pm 1.7$ & $32.2 \pm 1.4^{*}$
\end{tabular}

Values are expressed as mean \pm s.e.mean of the absorbance of $497 \mathrm{~nm}$ in areas of $0.04 \mathrm{~mm}^{2}$. Data are pooled across 20 series of 100 measurements each.

${ }^{*} P<0.01$.

$(1 \mu \mathrm{M})$, both possessing increased electrogenic $\mathrm{Na}^{+} / \mathrm{K}^{+}$-pumping, the ouabain binding was characterized by two sites $(P<0.005)$. Besides the high-affinity site (nM range) also found in non-treated myotubes, an additional low-affinity site ( $\mu \mathrm{M}$ range) was present (Figure $3 \mathrm{~b}, \mathrm{c}$; Table 2). The appearance of the low-affinity site accounted for a 4-5 fold increase in the total number of ouabain binding sites in myotubes treated with carbachol $(10 \mu \mathrm{M})$ or a combination of carbachol and chlorpromazine (1 $\mu \mathrm{M})$-treated myotubes (Table 2).

Antibody binding To obtain a more specific characterization of the increase in $\mathrm{Na}^{+} / \mathrm{K}^{+}$-ATPase activity of carbacholtreated myotubes, binding of two monoclonal antibodies was studied, i.e. McK1 (Felsenfeld \& Sweadner, 1988) and McB2 (Urayama et al., 1989) directed against $\alpha_{1}$ - or $\alpha_{2}$-subunits of $\mathrm{Na}^{+} / \mathrm{K}^{+}$-ATPase, respectively. Both antibodies stained the myotubes intracellularly and at the plasma membrane (not shown). Incubation of the myotubes for 4 days with carbachol $(10 \mu \mathrm{M})$ caused an increase in staining intensity of about $45 \%$ for both antibodies compared to non-treated myotubes (Table 3 ).

\section{Discussion}

The results presented here show that long-term treatment of $\mathrm{C} 2 \mathrm{C} 12$ myotubes with carbachol, measured in the absence of the agonist, induced a concentration-dependent increase in membrane potential of $\mathrm{C} 2 \mathrm{C} 12$ myotubes, caused by an increased $\mathrm{Na}^{+} / \mathrm{K}^{+}$-ATPase activity, accompanied by an increased binding of ouabain and $\mathrm{Na}^{+} / \mathrm{K}^{+}$-ATPase directed antibodies. The carbachol-induced increase in $\mathrm{Na}^{+} / \mathrm{K}^{+}$ATPase activity was abolished in the presence of pancuronium, but not by atropine at an equal concentration. Therefore, pancuronium showed a greater potency in antagonizing the carbachol-induced response than atropine, demonstrating that the carbachol-induced increase in $\mathrm{Na}^{+} /$ $\mathrm{K}^{+}$-ATPase activity was mediated by nicotinic rather than muscarinic AChRs (Buckett et al., 1968). It is unlikely that nicotinic AChR-mediated enhancement of $\mathrm{Na}^{+} / \mathrm{K}^{+}$-ATPase activity is caused by the depolarization of the myotubes, as long-term incubation in high $\mathrm{K}^{+}$medium failed to induce an excess $\mathrm{Na}^{+} / \mathrm{K}^{+}$-ATPase activity. Intracellular $\mathrm{Na}^{+}$might represent the mechanism responsible for the induction of

Table 2 The effect of long-term stimulation of nicotinic acetylcholine receptors (AChRs) on ouabain binding in C2C12 myotubes

$\begin{array}{lccccc}\text { Treatment } & \mathrm{n} & \begin{array}{c}\mathrm{K}_{\mathrm{dl}} \\ (\mathrm{nM})\end{array} & \begin{array}{c}\mathrm{K}_{\mathrm{d} 2} \\ (\mu \mathrm{M})\end{array} & \begin{array}{c}\mathrm{B}_{\max } \\ (\mathrm{fmol} \text { per well) }\end{array} & \begin{array}{c}\mathrm{B}_{\max } \\ (\mathrm{fmol} \text { per well) }\end{array} \\ \text { None } & 5 & 119 \pm 11 & - & 296 \pm 10 & - \\ \text { Carbachol } & 5 & 79 \pm 14 & 13 \pm 5^{*} & 227 \pm 27 & 983 \pm 35 \\ \text { Carbachol/CPZ } & 3 & 56 \pm 8 & 10 \pm 2^{*} & 160 \pm 14 & 1330 \pm 125\end{array}$

Cells had been incubated for 4 days in the presence of carbachol $(10 \mu \mathrm{M})$ or the combination of carbachol $(10 \mu \mathrm{M})$ and chlorpromazine $(\mathrm{CPZ} ; 1 \mu \mathrm{M})$. $\left.{ }^{3} \mathrm{H}\right]$-ouabain binding was measured after extensive washing of the drugs and is represented by the affinity $\left(K_{\mathrm{d} 1}, K_{\mathrm{d} 2}\right)$ and the number of associated binding sites $\left(B_{\max 1}, B_{\max 2}\right)$. Values are expressed as mean \pm s.e.mean of $n$ experiments.

*Represents the preference of a two-site binding model over a one-site model $(F$-test, $P<0.001)$. 
$\mathrm{Na}^{+} / \mathrm{K}^{+}$-ATPase activity in carbachol-stimulated $\mathrm{C} 2 \mathrm{C} 12$ myotubes. In chick myotubes, long-term treatment with veratridine to activate voltage-operated $\mathrm{Na}^{+}$-channels, upregulated $\mathrm{Na}^{+} / \mathrm{K}^{+}$-ATPase by increasing synthesis of the $\beta$-subunit of the enzyme for $24 \mathrm{~h}$ (Taormino \& Fambrough, 1990), followed by a decrease of the $\mathrm{Na}^{+} / \mathrm{K}^{+}$-ATPase degradation rate (Wolitzky \& Fambrough, 1986). However, it seems unlikely that an increase in nicotinic AChR-mediated intracellular $\mathrm{Na}^{+}$is responsible for the increase in $\mathrm{Na}^{+} / \mathrm{K}^{+}$ATPase activity of carbachol-stimulated $\mathrm{C} 2 \mathrm{C} 12$ myotubes, as carbachol-stimulated myotubes still developed enhanced $\mathrm{Na}^{+} / \mathrm{K}^{+}$-ATPase activity and increased ouabain binding in the presence of the nicotinic AChR ion-channel blocking agent, chlorpromazine. That different mechanisms are involved in the carbachol and veratridine induction of $\mathrm{Na}^{+} /$ $\mathrm{K}^{+}$-ATPase activity is supported by the time-course of the action of carbachol, being 3-4 fold longer than in veratridine-stimulated myotubes. These results show that the nicotinic AChR is not only a classical ligand-operated ionchannel (Changeux, 1990), but also regulates long-term cellular processes.

The development of enhanced $\mathrm{Na}^{+} / \mathrm{K}^{+}$-ATPase activity in carbachol-stimulated myotubes was accompanied by an increase of ouabain binding and an enhanced binding of monoclonal antibodies directed against the $\alpha_{1}$ - and the $\alpha_{2}$-subunit of the $\mathrm{Na}^{+} / \mathrm{K}^{+}$-ATPase. These results suggest that the increase in $\mathrm{Na}^{+} / \mathrm{K}^{+}$-ATPase activity of nicotinic AChR-stimulated myotubes is due to an increase in the number of $\mathrm{Na}^{+} / \mathrm{K}^{+}$-ATPase sites. An attempt to study involvement of de novo synthesis of $\mathrm{Na}^{+} / \mathrm{K}^{+}$-ATPase by incubating the carbachol-treated myotubes in the presence of chlorheximide $\left(1 \mu \mathrm{g} \mathrm{ml}^{-1}\right)$ was obstructed because of detachment of the cells within $48 \mathrm{~h}$. The development of the low-affinity binding site accounted for the increase in total ouabain binding. The existence of multiple ouabain binding sites has been attributed to the expression of different isozymes of the $\mathrm{Na}^{+} /$ $\mathrm{K}^{+}$-ATPase $\alpha$-subunit at the plasma membrane (Sweadner, 1989). In contrast, the development of a specific ouabain binding site in carbachol-treated myotubes was accompanied by an equal increase in binding of antibodies directed against the $\alpha_{1}$ - or $\alpha_{2}$-subunit of the $\mathrm{Na}^{+} / \mathrm{K}^{+}$-ATPase. This contradiction might be explained by the ability of the antibodies to bind to plasma membrane as well as to intracellular $\mathrm{Na}^{+} /$ $\mathrm{K}^{+}$-ATPase, thus being unable to detect $\alpha$-subunit specific $\mathrm{Na}^{+} / \mathrm{K}^{+}$-ATPase at the plasma membrane. Moreover, development of the low-affinity ouabain binding site might be dependent on mechanisms other than regulation of $\alpha$-subunit incorporation, such as e.g. phosphorylation of $\mathrm{Na}^{+} / \mathrm{K}^{+}$-
ATPase subunits (Vasilets et al., 1990; Chibalin et al., 1992). Nevertheless, although the precise molecular mechanism increasing the $\mathrm{Na}^{+} / \mathrm{K}^{+}$-ATPase binding in $\mathrm{C} 2 \mathrm{C} 12$ cells is poorly understood, our study clearly demonstrates that longterm stimulation of nicotinic AChRs results in an upregulation of $\mathrm{Na}^{+} / \mathrm{K}^{+}$-ATPase binding sites.

In view of the observation that the increased $\mathrm{Na}^{+} / \mathrm{K}^{+}-$ ATPase activity in carbachol-treated $\mathrm{C} 2 \mathrm{C} 12$ myotubes is independent of ion-transport, nicotinic AChR-mediated activation of a second messenger system should be considered. So far, stimulation of nicotinic AChRs has been shown to activate the phospholipase $C$ (PLC) route, inducing formation of inositol $(1,4,5)$ trisphosphate and mobilization of $\mathrm{Ca}^{2+}$ from internal stores in C2C12 myotubes (Grassi et al., 1993). The regulation of Xenopus oocyte $\mathrm{Na}^{+} / \mathrm{K}^{+}$-ATPase by protein kinase C (Vasilets et al., 1990), which is activated by the PLC route, suggests that the contribution of the PLC route in the induction of $\mathrm{Na}^{+} / \mathrm{K}^{+}$-ATPase activity in long-term nicotinic AChR-stimulated myotubes needs further attention.

Thus, long-term stimulation of nicotinic AChRs induced an adaptive response in $\mathrm{C} 2 \mathrm{C} 12$ myotubes, represented by an increase in $\mathrm{Na}^{+} / \mathrm{K}^{+}$-ATPase activity and a concomitant increase in membrane potential. In this respect, long-term stimulation of nicotinic AChRs of non-contracting $\mathrm{C} 2 \mathrm{C} 12$ myotubes serves as a model of innervation of skeletal muscle (Berg \& Hall, 1975; Chang et al., 1975; Mathers \& Thesleff, 1978; Pestronk et al., 1980). Further studies examining the involvement of nicotinic $\mathrm{AChRs}$ in the regulation of other innervation-related properties of skeletal muscle (Pestronk et al., 1980; Rogart \& Regan, 1985) are in progress.

In summary, we have shown that long-term activation of nicotinic AChRs in C2C12 myotubes increases the membrane potential by augmentation of electrogenic $\mathrm{Na}^{+} / \mathrm{K}^{+}$-pumping. This increase in $\mathrm{Na}^{+} / \mathrm{K}^{+}$-ATPase activity is associated with the appearance of an additional low-affinity $\left[{ }^{3} \mathrm{H}\right]$-ouabain binding site and an increase in binding of antibodies specific for $\alpha_{1}$ - and $\alpha_{2}$-subunits of the enzyme. Consequently, this study exposes the apparent ability of ligand-operated nicotinic AChRs to mediate adaptive responses of the cell upon chronic receptor activation.

Monoclonal antibodies McK1 and McB2 were a generous gift of Dr K.J. Sweadner. The assistance of A. Pasma and Dr G.J. ter Horst with the antibody staining is gratefully acknowledged. This study was partly sponsored by grant $900-549-133$ from The Netherlands Organisation for Scientific Research (NWO).

\section{References}

BERG, D.K. \& HALL, Z.W. (1975). Increased extrajunctional acetylcholine sensitivity produced by chronic post-synaptic neuromuscular blockade. J. Physiol., 244, 659-676.

BUCKETT, W.R., MAJORIBANKS, C.E.B., MARWICK, F.A. \& MOR TON, M.B. (1968). The pharmacology of pancuronium bromide (Org. Na 97), a new potent steroidal neuromuscular blocking agent. Br. J. Pharmacol. Chemother., 32, 671-679.

CHANG, C.C., CHUANG, S.T. \& HUANG, M.C. (1975). Effects of chronic treatment with various neuromuscular blocking agents on the number and distribution of acetylcholine receptors in the rat diaphragm. J. Physiol., 250, 161-173.

CHANGEUX, J.P. (1990). The nicotinic acetylcholine receptor: an allosteric protein prototype of ligand-gated ion channel. Trends Pharmacol. Sci., 11, 485-492.

CHIBALIN, A.V., VASILETS, L.A., HENNEKES, H., PRALONG, D. \& GEERING, K. (1992). Phosphorylation of Na,K-ATPase $\alpha$-subunits in microsomes and in homogenates of Xenopus oocytes resulting from the stimulation of protein kinase $A$ and protein kinase C. J. Biol. Chem., 267, 22378-22384.

DRACHMAN, D.B. \& WITZKE, F. (1972). Trophic regulation of acetylcholine sensitivity of muscle: effect of electrical stimulation. Science, 176, 514-516.
FELSENFELD, D.P. \& SWEADNER, K.J. (1988). Fine specificity mapping and topography of an isozyme-specific epitope of the $\mathrm{Na}, \mathrm{K}$ ATPase catalytic subunit. J. Biol. Chem., 263, 10932-10942.

GRASSI, F., GIOVANNELli, A., FUCILE, S. \& EUSEBI, F. (1993). Activation of the nicotinic acetylcholine receptor mobilizes calcium from caffeine-insensitive stores in $\mathrm{C} 2 \mathrm{C} 12$ mouse myotubes. Pflügers Arch., 422, 591-598.

HENNING, R.H., NELEMANS, S.A., VAN DEN AKKER, J. \& DEN HERTOG, A. (1992). The nucleotide receptors on mouse C2C12 myotubes. Br. J. Pharmacol., 106, 853-858.

HOGUE, C.W., WARD, J.M., ITANI, M.S. \& MARTYN, J.A.J. (1992). Tolerance and upregulation of acetylcholine receptors follow chronic infusion of $d$-tubocurarine. J. Appl. Physiol., 72, 13261331.

MATHERS, D.A. \& THESLEFF, S. (1978). Studies on neurotrophic regulation of murine skeletal muscle. J. Physiol., 282, 105-114.

MUNSON, P.J. \& RODBARD, D. (1980). LIGAND: a versatile computerized approach for characterization of ligand-binding systems. Annal. Biochem., 107, 220-225.

PESTRONK, A., DRACHMAN, D.B. \& GRIFFIN, J.W. (1976). Effect of botulinum toxin on trophic regulation of acetylcholine receptors. Nature, 264, 787-789. 
PESTRONK, A., DRACHMAN, D.B., STANLEY, E.F., PRICE, D.L. \& GRIFFIN, J.W. (1980). Cholinergic transmission regulates extrajunctional acetylcholine receptors. Exp. Neurol., 70, 690-696.

ROGART, R.B. \& REGAN, L.J. (1985). Two subtypes of sodium channel with tetrodotoxin sensitivity and insensitivity detected in denervated mammalian skeletal muscle. Brain Res., 329, 314-318.

SIMPSON, L.L. (1977). The effects of acute and chronic botulinum toxin treatment on receptor number, receptor distribution and tissue sensitivity in rat diaphragm. J. Pharmacol. Exp. Ther., 200, $343-351$

SWEADNER, K.J. (1989). Isozymes of $\mathrm{Na}^{+} / \mathrm{K}^{+}$-ATPase. Biochim. Biophys. Acta, 988, 185-220.

TAORMINO, J.P. \& FAMBROUGH, D.M. (1990). Pre-translational regulation of the $\left(\mathrm{Na}^{+} / \mathrm{K}^{+}\right)$-ATPase in response to demand for ion transport in cultured chicken skeletal muscle. J. Biol. Chem., 265, 4116-4123.

URAYAMA, O., SHUTT, H. \& SWEADNER, K.J. (1989). Identification of three isozyme proteins of catalytic subunit of the $\mathrm{Na}, \mathrm{K}$ ATPase in rat brain. J. Biol. Chem., 264, 8271-8280.
VASILETS, L.A., SCHMALZING, G., MÄDEFESSEL, K., HAASE, W. \& SCHWARTZ, W. (1990). Activation of protein kinase C by phorbol ester induces downregulation of the $\mathrm{Na}^{+} / \mathrm{K}^{+}$-ATPase in oocytes of Xenopus laevis. J. Membr. Biol., 118, 131-142.

WOLITZKY, B.A. \& FAMBROUGH, D.M. (1986). Regulation of the $\left(\mathrm{Na}^{+} / \mathrm{K}^{+}\right)$-ATPase in cultured chick skeletal muscle. J. Biol. Chem., 261, 9990-9999.

WOLTERS, G.H.J., PASMA, A., WIEGMAN, J.B. \& KONIJNENDIJK, W. (1984). Glucose-induced changes in histochemically determined $\mathrm{Ca}^{2+}$ in $\mathrm{B}$-cell granules, ${ }^{45} \mathrm{Ca}$ uptake, and total $\mathrm{Ca}^{2+}$ of rat pancreatic islets. Diabetes, 33, 409-414.

YAFFEE, D. \& SAXEL, O. (1977). Serial passage and differentiation of myogenic cells isolated from dystrophic mouse muscle. Nature, 270, 725-727.

(Received July 30, 1993

Revised October 5, 1993 Accepted October 12, 1993) 